\title{
A Responsabilidade Política: UMA CONTEXTUALIZAÇÃO CRÍTICA A PARTIR DE PIERRE ANSART*
}

\author{
ANDREY LUCAS MACÊDO CORRÊA ${ }^{\dagger}$ \\ ALEXANDRE WALMOTT BORGES ${ }^{\dagger \dagger}$
}

RESUMO: O artigo apresenta o tema da responsabilidade política contemporânea com o enfoque crítico de Pierre Ansart sobre os sistemas representativos democráticos. A dinâmica do artigo é de delineamento da ideia de responsabilidade política, seguido da inserção da responsabilidade política no sistema de democracia representativa, e a responsabilidade política como aspecto formal e material das democracias representativas. Ao final, com as contextualizações de Pierre Ansart expostas em "Mal-Estar ou fim dos amores políticos", faz-se a crítica da responsabilidade política nos sistemas democráticos representativos atuais. Busca-se especial análise de modelos concretos de

\footnotetext{
* O presente artigo foi elaborado no âmbito do Laboratório Americano de Estudos Constitucionais Comparados (LAECC-PPGD/UFU) e contou com apoio financeiro da Coordenação de Aperfeiçoamento de Pessoal de Nível Superior (CAPES) e da Fundação de Amparo à Pesquisa do Estado de Minas Gerais (FAPEMIG).

${ }^{\dagger}$ Bacharelando em Direito pela Universidade Federal de Uberlândia-UFU com período de mobilidade internacional na Universidade de Coimbra-Portugal. Bolsista de iniciação científica do Conselho Nacional de Desenvolvimento Científico e Tecnológico - CNPq e bolsista de mobilidade internacional pela UFU. Pesquisador no Centro de Estudos Sociais da Universidade de Coimbra - CES/UC e pesquisador do Laboratório Americano de Estudos Constitucionais Comparados - LAECC/PPGD-UFU. E-mail: andreylucas93@hotmail.com.

† Professor Associado da Universidade Federal de Uberlândia - UFU, Professor do programa de mestrado em Direito, Uberlândia, MG, Brasil; Professor Visitante da Universidade Estadual Paulista Júlio de Mesquita - UNESP, programa de mestrado em Direito, Franca, SP, Brasil. Mestre e Doutor em Direito do Estado pela UFSC;

Doutorando em História Social pela UFU; Especialista em História e Filosofia da Ciência. Coordenador do Laboratório Americano de Estudos Constitucionais Comparados - LAECC/PPGD-UFU. E-mail: walmott@gmail.com.
} 
responsabilidade política atuais, com ênfase nas delimitações políticonormativas da República Brasileira e dos Estados Unidos da América. Na confecção do texto, utilizaram-se as seguintes fontes: material bibliográfico envolvendo obras da teoria política clássica da modernidade, periódicos, materiais de sítios eletrônicos informativos e fontes documentais legislativas. Para o fechamento da problematização utilizou-se o texto de Pierre Ansart publicado na revista "História e perspectivas".

PalaVRAS-ChAVE: Sistemas Representativos; Responsabilidade Política; Democracia; Pierre Ansart.

ABSTRACT: The article presents the theme of contemporary political responsibility with the critical focus of Pierre Ansart about democratic representative systems. The dynamics of this article is to outline the idea of the political responsibility, followed by the insertion of political responsibility in the system of representative democracy and political responsibility as a formal and material aspect of representative democracies. At the end, with exposed Pierre Ansart" contextualization in "Mal-being or end of political love", it is made the critique of political responsibility in the current representative democratic systems. We seek special analysis of concrete models of current political responsibility, with emphasis on political and normative boundaries of the Brazilian Republic and of the United States of America. In this research the following sources were used: bibliographic material involving works of classical political theory of modernity, journals, materials of electronic information sites and parliamentary documentary sources. To the closing of questioning was used the text of Pierre Ansart published in the journal "History and Perspectives".

KEYWORDS: Representative Systems; Democracy; Political Accountability; Pierre Ansart. 


\section{SUMÁRIO:}

I. INTRODUÇã̃ ..........................................................................................336

II. AS CONSIDERAÇÕES INICIAIS: DELINEAMENTO DA

RESPONSABILIDADE POLÍTICA.

III. A RESPONSABILIDADE POLÍTICA: VÍNCULO, RELAÇÃo, OBJETO E SUJEITOS......................................................................................340

IV. RESPONSABILIDADE EM CONTRASTE COM OUTROS ELEMENTOS DA POLÍTICA ...........................................................................................343

V. A RESPONSABILIDADE POLÍ́TICA EM MODELOS CONCRETOS.............346

VI. A RESPONSABILIDADE POLÍTICA CONTEMPORÂNEA: UMA CRÍTICA A PARTIR de PIERRE ANSART ......................................351

VII. CONSIDERAÇõ ES FINAIS .......................................................................360

VIII. REFERÊNCIAS..........................................................................................360

\section{TABLE OF CONTENTS:}

I. INTRODUCTION ......................................................................................336

II. THE INITIAL CONSIDERATIONS: CONSIDERAÇÕES INICIAIS: THE OUTLINE OF POLITICAL ACCOUNTABILITY ..................................337

III. THE POLITICAL ACCOUNTABILITY: BOND, RELATION, OBJECT, AND SUBJECTS...........................................340

IV. ACCOUNTABILITY IN CONTRAST WITH OTHER ELEMENTS OF POLITICS.................................................................343

V. THE POLITICAL ACCOUNTABILITY IN CONCRETE MODELS ...............346

VI. THE CONTEMPORARY ACCOUNTABILITY: A CRITICISM FROM PIERRE ANSART ...................................................351

VII. FINAL CONSIDERATIONS.........................................................................360

VIII. REFERENCES ...........................................................................................360 


\section{INTRODUÇÃO}

O presente trabalho abordará o tema da responsabilidade política a partir do enfoque crítico de Pierre Ansart. O principal foco será analisar o fenômeno da crise do sistemas representativos, definido pelo autor como "fim dos amores políticos" ${ }^{1}$. Dessa forma, inicia-se o debate com a busca por uma conceituação histórica e teórica sobre a responsabilidade política, evidenciando a existência de uma linha contínua entre os modelos pré-Estados Modernos, perpassando estes e culminando nos atuais Estados Democráticos de Direito.

Avança-se nesta delimitação sobre responsabilidade política, sobretudo no que tange a relação sujeito-objeto e sujeito-sujeito, encontrando uma verdadeira conexão entre os "súditos" das monarquias absolutistas até aos "cidadãos" dos regimes atuais. Em seguida, busca-se demonstrar como essas relações podem ser observadas em modelos concretos, em especial no que tange a responsabilidade dos governantes. Busca-se evidenciar que estes modelos culminam, invariavelmente, para a crise político-institucional, que abarca tanto dimensões formais (institucionalidade e procedimentos) quanto dimensões materiais (legitimidade e participação) nas democracias modernas.

Na produção do artigo são utilizadas as seguintes fontes para buscar o embasamento necessário: material bibliográfico envolvendo obras da teoria política clássica da modernidade, periódicos, materiais de sítios eletrônicos informativos e fontes documentais legislativas. Para o fechamento da problematização utilizou-se o já referenciado texto de Pierre Ansart publicado na revista "História e perspectivas".

O texto finda com a tentativa de crítica aos modelos democráticos com relação à responsabilidade política, revelando que os modelos anteriores e atuais não conseguem buscar legitimidade nas formas tradicionais da participação política, o que gera consequências profundas tanto para os desenhos institucionais quanto para a práxis democrática. Busca-se o foco desta crítica nas dimensões emocionais da política, demonstrando a incapacidade do modelo institucional de matriz liberal para responder e representar uma sociedade essencialmente emocional (tanto individual quanto politicamente) a partir de um modelo de racionalidade avalorativa.

${ }^{1}$ ANSART, Pierre. Mal-estar ou fim dos amores políticos. Revista História \&

Perspectivas, No. 25/26, 2002. 


\section{AS CONSIDERAÇÕES INICIAIS: DELINEAMENTO DA RESPONSABILIDADE POLÍTICA}

A abordagem do tema da responsabilidade política neste artigo iniciase por delineação do significado da expressão. O termo responsabilidade política apresenta vaguezas e ambiguidades e, quando muito, certo núcleo de clareza encontra-se na ideia de que, na responsabilidade política, o governante assume compromissos e obrigações e, como consequência, deve honrar com tais compromissos afiançados perante o corpo dos governados. De forma mais objetiva, na responsabilidade política o governante responde aos governados por tais obrigações, compromissos e promessas, no exercício do cargo, ou da função (tome-se esse sentido ao início como uma definição lexical da expressão responsabilidade). Tal zona de luminosidade da expressão deixa campo a várias sombras e imprecisões ${ }^{2}$ e, ao longo do texto, desenham-se algumas redefinições e estipulações do termo, adequando-o aos sentidos político e jurídico. ${ }^{3}$

Sobre o uso da expressão responsabilidade como o vínculo de obrigações jurídicas e políticas entre o governante e os governados, devese dizer que este sentido não era de utilização corrente pelo menos até o século XVII. Na política, não se compreendia que, nas relações políticas, pudesse o governante responder aos súditos, ou seja, não se encaixava no sentido etimológico de responder, respondere do latim clássico: spondere,

2 Além disso, tais imprecisões são verificadas, tanto nos modelos representativos "ocidentais", quanto nas perspectivas intentadas pelo socialismo soviético. No entanto, neste, mesmo que a nível teórico, havia um reconhecimento relativo à menor eficiência legitimadora de modelos com menos graus de representação, defendendo-se um sistema representativo múltiplo em instâncias e em ambientes. REPÚBLICA DEMOCRÁTICA ALEMÃ. Democracia Socialista: Participação nas decisões, Responsabilidade, Direitos, Liberdades. Dresden: PANORAMA RDA - Agência de Imprensa para o estrangeiro, 1981, p. 29-34.

3 "Si l'on prend en compte les emplois du terme « responsabilité », tant dans la morale que dans le droit, on peut constater que les significations qu'il véhicule sont loin d'être univoques. Le succès de la responsabilité serait même lié à sa capacité de créer des équivoques. Cette polysémie de la responsabilité peut se révéler féconde, car à côté du champ sémantique lié à l'idée d'imputation, il ya d'autres possibles dimensions de sens attachées à l'idée d' «être responsable »". GORGONI, Guido. La responsabilité comme projet. Réflexions sur une responsabilité juridique « prospective ». In: Christoph Eberhard (ed.). Traduire nos responsabilités planétaires: Recomposer nos paysags juridiques. Bruxelas: Bruylant, 2008, p. 58.

2 JOURNAL OF INSTITUTIONAL STUDIES 1 (2016) 
garantir, prometer, e re, de voltar, ir para trás. Responder é prestar contas àquilo que prometeu. Utilizando-se o significado contemporâneo da expressão, o governante era, se comparado aos padrões atuais, irresponsável perante os súditos, ao menos nas formas nas quais pudesse ser sancionado com perda do cargo e com sanções políticas, e de que, ao assumir as atribuições responsáveis do cargo, o próprio exercício "responsável" o legitimasse perante os governados. O universo de relações entre o governante e os súditos envolvia outras formas como ordenação orgânica da vida comunitária e social, sem o vínculo relacional obrigacional imediato entre detentor do poder político e o súdito. A entronização por critérios dinásticos e de fundamento divino não incluíam a responsabilização do governante. Por isso Camões fala que:

E não sei por que influxo de Destino

Não tem um ledo orgulho e geral gosto,

Que os ânimos levanta de contino

A ter pera trabalhos ledo o rosto.

Por isso vós, ó Rei, que por divino

Conselho estais no régio sólio posto,

Olhai que sois (e vede as outras gentes)

Senhor só de vassalos excelentes" ${ }^{\prime 4}$

Ainda sobre o tema, a Constituição imperial brasileira do século XIX assim dizia: "Art. 99. A Pessoa do Imperador é inviolavel, e Sagrada: Elle não está sujeito a responsabilidade alguma"

No direito, ao menos no sistema clássico do direito privado, o sistema obrigacional do direito romano não contemplava formas de cumprimento que não fossem decorrentes de um vínculo privado (e não na esfera pública da política) estabelecido entre credor e devedor. Noutras palavras, não haveria obrigação decorrente de um fato político, como a responsabilidade jurídica moderna determina. $^{6} \mathrm{O}$ uso do termo

${ }^{4}$ CAMÕES, Luís Vaz de. Os Lusíadas, 2008. Disponível em:

$<$ http://oslusiadas.org/x/146.html $>$. Acesso em: 20 de dezembro de 2015.

${ }^{5}$ BRASIL. Constituição do Império do Brazil. Rio de Janeiro, RJ: Presidência da República, 1824.

${ }^{6}$ É importante salientar que o direito atual divide a responsabilidade em responsabilidade decorrente de contrato, contratual, e aquela que não decorre de contrato, extracontratual. A sponsio romana decorria originalmente de vínculo contratual e não de um fato outro, como a moderna responsabilidade extracontratual. Assim, para admitir a aplicação da responsabilidade nos moldes do direito romano 
responsabilidade no direito privado prodigalizou-se no século XIX, abarcando, tanto as obrigações decorrentes de manifestação volitiva, como aquelas decorrentes de atos ou fatos. ${ }^{7}$ Deve-se salientar que o conceito de responsabilidade insere-se no direito como consequência de vínculos privados obrigacionais, e não de relações públicas-políticas.

Com as duas informações sobre o uso da palavra na política, e no direito, pode-se ver que a responsabilidade política é decorrência então da confluência entre as formas pactistas e contratualistas do século XVII em diante, e o advento do constitucionalismo. ${ }^{8} \mathrm{Na}$ política, é a partir do século XVII que o termo responsabilidade passa a circular nos escritos políticos como específica forma relacional entre governantes e governados. No campo do direito político e do direito público, é a partir do século XIX que a palavra responsabilidade migra do sentido original dos contratos e do direito privado para uma mais ampla acepção republicana.

clássico ao sistema político, ter-se-ia que subsumir toda a relação entre governante e governado aos moldes do direito privado, como se houvesse um contrato entre um, e outro. “Da sponsio, então, decorria uma responsabilidade que só se efetivaria no caso de descumprimento da prestação, e é por isso que, na obrigação antiga, o ponto de vista da responsabilidade se coloca em primeiro plano. O debitum - relação de crédito e dívida nascido do empréstimo de consumo, que difere do nexum por não ser um ato que obrigue o pagamento - se funde à obligatio justamente com a sucessiva evolução da sponsio, daí surgindo o conceito unitário de obrigação". TABORDA, Marem Guimarães. Estudo sobre o procedimento civil e as obrigações no direito romano clássico. Disponível em: <http://www.ufrgs.br/ppgd/doutrina/taborda2.htm>. Acesso em: 17 de julho de 2016.

${ }^{7}$ A ideia de responsabilidade como decorrência de fato ou ato, e não de manifestação de vontade contratual, foi resgatada da lex aquilia, do direito romano, já no figurino das modernas codificações do século XIX: "Il est peut-être plus difficile de découvrir la place de la volonté dans les délits ou les quasi-délits. Mais, toujours en remontant au droit romain, c'est-à-dire à la Loi Aquilia, avec la notion de «damnum iniuriadatum», on retrouve l'obligation de sécurité vou-lue par le droit qui rejoint d'ailleurs la notion d'acte illicite qui fait nécessairement inter-venir la volonté. C'est l'explication qui figure dans l'article 1382 l'article 1382 du code civil à propos du fait fautif qui cause un dommage et «oblige» celui qui l'a causé à le réparer". DRAGO, Roland. La notion dóbligation: droit publique et droit privé. Archives de philosophie du droit, Vol. 44, 2000, p. 43-49.

8 Entendendo-se o constitucionalismo como consequência das teorias pactistas e contratualistas do século XVIII. 


\section{A RESPONSABILIDADE POLÍTICA: VÍNCULO, RELAÇÃO, OBJETO E SUJEITOS}

A ideia de responsabilidade guarda ligação com a existência de vínculo e que este vínculo gera o compromisso, ou a obrigação entre os compromissados. Algumas observações básicas decorrem desta ligação política e jurídica entre os compromissados. Primeiro, se há compromissados ou obrigados, este vínculo nasce da relação política entre eles. Assim, há o vínculo que, em linhas gerais, há de ser descrito entre o governante e o governado (dois sujeitos). Segundo, o compromisso ou obrigação envolve algo, um objeto. De forma a elaborar síntese apertada, há, na ideia material e formal de responsabilidade política, os sujeitos e o objeto da relação.

A existência do vínculo entre o governante e o governado não gera, per se, a responsabilização do governante. Por exemplo, para Hobbes, a assunção do governante é ato autorizador de exercício de autoridade ilimitada. ${ }^{9}$ A ação ilimitada do governante por certo não lhe impõe responder aos governados. ${ }^{10} \mathrm{O}$ ato autorizador entrega à autoridade prerrogativas que não a obrigam a responder ao governado. A representação ou governação em Hobbes não sofre limites.

Este ponto leva à consideração crítica de que a responsabilidade, além

9 Tendo em vista que, para o autor, o bem que deve ser protegido pelo governante na instituição do pacto social é a "vida". Cf. VIEIRA, Mónica Brito. The Elements of Representation in Hobbes: Aesthetics, Theatre, Law, and Theology in the Construction of Hobbes's Theory of State. Boston, MA: Brill, 2009.

10 "From hence it followeth, that when the Actor maketh a Covenant by Authority, he bindeth thereby the Author, no lesse than if he had made it himselfe; and no lesse subjecteth him to all the consequences of the same. And therfore all that hath been said formerly, (Chap. 14.) of the nature of Covenants between man and man in their naturall capacity, is true also when they are made by their Actors, Representers, or Procurators, that have authority from them, so far-forth as is in their Commission, but no farther. And therefore he that maketh a Covenant with the Actor, or Representer, not knowing the Authority he hath, doth it at his own perill. For no man is obliged by a Covenant, whereof he is not Author; nor consequently by a Covenant made against, or beside the Authority he gave". HOBBES, Thomas. Hobbes's Leviathan reprinted from the edition of 1651. Oxford/Indianapolis, IN: Clarendon Press/Liberty fund, 1909. As expressões são do inglês do século de publicação original já que se trata de versão copiada eletronicamente do original. 
da identificação dos sujeitos envolvidos e do objeto que relaciona esses sujeitos, também se realiza em ambiente típico. Qual seja, a responsabilidade depende de certas condições ambientais institucionais e sociais para que ocorra. A responsabilidade política existe na democracia e com sistemas representativos. O "soberano" de Hobbes e de Carl Schmitt não responde politicamente aos súditos pois a sacralidade da investidura não importa em sinalagma com o súdito. Importa em majestade e não em responsabilidade. O sentido de representação de Hobbes está distante da ideia de obrigações sinalagmáticas entre o governante e o governado. Em Hobbes, como Carl Schmitt resgata, o vínculo entre o governante e o governado está revestido de sacralidade. A teologia da política é que dita a assunção do governante e este não presta contas, nem responde ao governado. ${ }^{11}$

Em sentido diferente, Maquiavel vê que $O$ Príncipe tem alguns deveres para com os governados. ${ }^{12}$ Aceitando-se alguma teleologia em $O$ Príncipe, as obrigações do governante são no sentido de realização moral do Principado, para a realização dos fins do Estado. Assim, embora também em Maquiavel não se possa ver o sinalagma entre o governante e o governado, ao contrário de Hobbes, há bilateralidade na relação entre governante e governado. Em Maquiavel, O Príncipe dita as ações em função de certas finalidades de valorização da Monarquia ou da República. Nisso, em Maquiavel também não há algum tracejo claro de como O Príncipe responderia aos governados, a não ser que se considere a responsabilidade como algo fluido, impregnado de leitura moral sobre a boa condução do Estado e da realização do bem para o povo. ${ }^{13} \mathrm{Em}$ Hobbes há a verticalização soberana, divina, e, em Maquiavel, já há

11 "La constitución vale por virtu de la voluntad politicapolítica de aquel que la da". SCHMITT, Carl. Teoría de la constitución. Madri: Alianza Editorial, 1996, p. 46. Cf. HOBBES, Thomas. Hobbes's Leviathan reprinted from the edition of 1651. Oxford/Indianapolis, IN: Clarendon Press/Liberty fund, 1909; AGAMBEN, Giorgio. Estado de Exceção. São Paulo, SP: Boitempo, 2004; e SCHMITT, Carl. Political theology: Four chapters of the concept of sovereignty. Cambridge, MA: The MIT Press, 1985.

${ }^{12}$ Cf. MAQUIAVEL, Nicolau. O Príncipe. São Paulo, SP: Martin Claret, 1999.

13 "Portanto, aqueles dentre os nossos príncipes que mantiveram seus domínios por muitos anos não devem acusar a sorte por tê-los perdido, mas sim sua própria indolência. [...]. Só são boas, seguras e duráveis aquelas defesas que dependem exclusivamente de nós, e do nosso próprio valor". MAQUIAVEL, Nicolau. O Príncipe. São Paulo, SP: Martin Claret, 1999, p. 138. A obra de Maquiavel indica ideia muito difusa de responsabilidade decorrente de atributos morais que $O$ Príncipe deve seguir para dar resposta ao que o povo quer.

2 JOURNAL OF INSTITUTIONAL STUDIES 1 (2016) 
alguma bilateralidade tendo em vista que O Príncipe também governa para o bem dos súditos.

Já no período das revoluções liberais inglesas, Robert Filmer sustenta que o poder real era encargo natural de ancestralidade e de linhas familiais. ${ }^{14}$ Filmer redige o texto em 1680 e sustenta o caráter divino e inconteste do rei, negando que ao monarca incumba qualquer responsabilidade aos súditos. Interessa notar que Filmer coloca-se inclusive contra as construções anteriores da escolástica que tencionavam fundamentar o poder do rei em limites circunstanciados pela liberdade do povo. Uma das inferências que se pode extrair da obra de Filmer é a tentativa de fundamentação no direito natural do poder irresponsável do rei.

É com John Locke que os contornos da responsabilidade política assumem os contornos de vínculo de confiança no sistema representativo. Uma confiança compromissada e sujeita às sanções, envolvendo governantes e governados. O governante ${ }^{15}$ responde "perante alguém", o governado. Para que esta relação governante-governado assuma alguma feição ou contorno mínimo, é conformado pelo ordenamento constitucional do Estado. Assim, a responsabilidade ocorre no Estado constitucional e é forma de limite de poder (em contraposição ao absoluto de Hobbes, ou mesmo de um limite de moralidade finalística, como em Maquiavel). ${ }^{16}$

${ }^{14}$ Cf. FILMER, Sir Robert. Patriarcha of the Natural Power of Kings. London: Richard Chiswell, 1680.

15 Tendo em vista que tal desenvolvimento acompanhou também a mudança institucional no sentido da "separação dos poderes", a figura do governante torna-se vária, passa de uma figura central para algumas figuras centrais. Para uma análise sobre um desses atores, o juiz, importante é a reflexão histórica de LAURIS, Élida. Entre a neutralidade política e a responsabilidade social: os dilemas de afirmação da independência judicial no Estado Moderno. Meritum, Vol. 6, 2, 2011, p. 235-238. ${ }^{16}$ Assim diz Locke: “[...] ninguém pode ser privado desta condição a liberdade nem colocado sob o poder político de outrem sem o seu consentimento [...] é necessário que esse corpo se mova na direção determinada pela força predominante, que é o consentimento da maioria. [...] Por conseguinte, todo o homem, ao consentir com os outros em formar um único corpo político sob um governo único, assume a obrigação, perante todos os membros dessa sociedade, de submeter-se à determinação da maioria e acatar a decisão desta. [...] cabe ainda ao povo um poder supremo para remover ou alterar o legislativo quando julgar que este age contrariamente à confiança nele depositada" [...] "Em todos os casos, enquanto subsistir o governo, o legislativo é o poder supremo. [...] deve por força ser o poder supremo, e todos os demais poderes 


\section{RESPONSABILIDADE EM CONTRASTE COM OUTROS ELEMENTOS DA POLÍTICA}

Da forma como foram dispostas as ideias, há a associação entre o poder político e a responsabilidade política. Todavia, o espectro do poder político é maior do que o espectro da responsabilidade política. A responsabilidade política é uma decorrência da posse e ocupação do cargo ou do mister, no Estado, e, como visto, nos limites definidos pelo ordenamento jurídico. Em maiores detalhes, responderá o agente que ocupa o cargo ou a função pública (embora também se possa imaginar que a função possa ser exercida sem cargo). E nem todo o poder político encontra-se naquele (ou naqueles) que ocupa(m) cargo(s). Por isso, nem toda a forma de poder político acarreta a responsabilização política (nos moldes de correspondência cargo/função-responsabilidade). ${ }^{17}$

Outro ponto de discussão que apresenta considerações críticas como essas da ideia de poder político $x$ ideia de responsabilidade política, é aquele da relação entre confiança e responsabilidade. Outra vez, a confiança ocupa espectro maior que o de responsabilidade política. Como analisa Pedro Lomba, a confiança é um dos pressupostos do pacto governativo de que fala Locke, mas não apresenta a densidade e a concreticidade da responsabilidade política. A responsabilidade envolve a processualização e a determinação de conteúdos (conteúdos e processo previstos em normas) ausentes na confiança, que é de materialidade difusa e imprecisa (e processualmente idealizada). ${ }^{18}$

depositados em quaisquer membros ou partes da sociedade devem derivar dele ou ser-lhe subordinados" [...] "O poder executivo quando não estiver depositado numa pessoa que também participe do legislativo, estará visivelmente subordinado a este e a ele responde, podendo ser trocado e deslocado à vontade; [...]". LOCKE, John. Dois tratados sobre o governo. São Paulo, SP: Martins Fontes, 1998, p. 468-470/518-520. ${ }_{17}$ Cf. LOMBA, Pedro. Teoria da responsabilidade política. Coimbra: Coimbra, 2008, p. 70-72.

${ }^{18}$ Cf. LOMBA, Pedro. Teoria da responsabilidade política. Coimbra: Coimbra, 2008, p. 70-72. É importante mencionar que as palavras "desconfiança" e "confiança" aparecem em normas constitucionais de governo de sistemas parlamentares. Por óbvio, estão distantes do sentido pactista de confiança de Locke e próximos ao sistema de responsabilidade política. Como exemplo, a Constituição brasileira de 1946 (Emenda Constitucional $n^{\circ} 4 / 1961$ ): Art. $9^{\circ}$ O Conselho de Ministros, depois de nomeado, comparecerá perante a Câmara dos Deputados, a fim de apresentar seu programa de govêrno. Parágrafo único. A Câmara dos Deputados, na sessão subseqüente e pelo 
Outra interessante consideração sobre a responsabilidade política é entre esta e a representação política. Assim, os processos eleitorais são processos de responsabilização. A cada período de eleições regulares o governante é exposto à responsabilização por seus eleitores. Novamente, a responsabilidade política guarda sentido mais estreito e não se sujeita exclusivamente aos pleitos periódicos. Certo é que os eleitores elegem premiam - governantes; eleitores sancionam governantes - não os reelegendo..$^{19}$ Isso gera alguma confusão entre o sentido de escolha e de responsabilização e não é apropriado à realidade da responsabilidade política. ${ }^{20}$

voto da maioria dos presentes, exprimirá sua confiança no Conselho de Ministros. A recusa da confiança importará de nôvo Conselho de Ministros. Art. 10. Votada a moção de confiança, o Senado Federal, pelo voto de dois terços de seus membros, poderá, dentro de quarenta e oito horas, opor-se à composição do Conselho de Ministros. Parágrafo único. $\mathrm{O}$ ato do Senado Federal poderá ser rejeitado, pela maioria absoluta da Câmara dos Deputados, em sua primeira sessão. Art. 11. Os Ministros dependem da confiança da Câmara dos Deputados e serão exonerados quando êste lhe fôr negada. Art. 12. A moção de desconfiança contra o Conselho de Ministros, ou de censura a qualquer de seus membros, só poderá ser apresentada por cinqüenta Deputados no mínimo, e será discutida e votada, salvo circunstância excepcional regulada em lei, cinco dias depois de propostas, dependendo sua aprovação do voto da maioria absoluta da Câmara dos Deputados. BRASIL. Emenda Constitucional $\mathbf{n}^{\circ}$ 4/1961. Disponível em:

<http://www.planalto.gov.br/ccivil 03/Constituicao/Emendas/Emc anterior1988/emc0 4-61impressao.htm>. Acesso em: 15 de janeiro de 2016.

${ }^{19}$ Considerando um sistema clássico em que existem mecanismos de responsabilidade política que "revogam" o mandato. Exemplos desses mecanismos são o recall político (em destaque no modelo estadunidense) e o abberufungsrecht (em destaque no modelo de alguns Cantões Suíços), sendo que no primeiro há a revogação de um mandato individual (do executivo, do legislativo ou do judiciário) e no segundo há ainda a possibilidade de revogação de todo um órgão, ou seja, uma dimensão mais abrangente do droit révocation.

20 "Governos são responsáveis na medida em que os cidadãos podem discernir se os governantes estão agindo de acordo com os seus interesses e sancioná-los apropriadamente, de forma que os governantes que satisfazem os cidadãos permanecem em seus postos e aqueles que não os satisfazem perdem suas posições. A responsabilidade política é um mecanismo retrospectivo, no sentido de que as ações dos governantes são julgadas a posteriori, em termos dos efeitos que causam". CHEIBUBI, José Antônio; PRZEWORSKI, Adam. Democracia, eleições e 
Apenas para a formalização explicativa, tem-se: a responsabilidade política $\subset$ a confiança; a responsabilidade está contida na confiança; a responsabilidade política $\subset$ a representação política; a responsabilidade está contida na representação política; a responsabilidade política $\subset$ no poder político; a responsabilidade está contida no poder político.

Alguns outros sentidos paralelos, mais amplos, ou mais restritos, da realidade institucional estatal também podem ser encontrados à margem, englobando ou englobados pela ideia de responsabilidade política: as possibilidades de accountability do sistema anglo-saxão; a fiscalização de contas do sistema dos Tribunais de Contas (TC) brasileiros; a ideia geral de prestação de contas do governante; o dever de publicidade. Todos têm continência com o conceito de responsabilidade política mas não são seus sinônimos.

Numa dimensão de maior juridicidade, há de se diferenciar a responsabilidade política de outras responsabilidades. Assim, há responsabilização penal-criminal, que consiste na aplicação de sanções aos comitentes de ilícitos criminais. Embora o surgimento da responsabilidade política possa ser encontrada em formas de punição criminal de agentes do Estado, no sistema inglês (inclusive a origem da expressão próxima da responsabilidade política, mas que com essa não se confunde, o impeachment), o sistema de sanção política distancia-se do sistema penal-punitivo. ${ }^{21}$ Há responsabilização administrativa aos agentes do Estado que consiste em aplicações de sanções funcionais (relacionadas ao cargo/função) ou pecuniárias e reparativas. Com relação ao último, há também as reparações civis e patrimoniais, também uma forma de responsabilização possível dos agentes do Estado. Todas as formas distinguem-se da natureza própria e delineadas na responsabilidade política. A responsabilidade política é: responsabilidade entre governantes e governados; é decorrência do vínculo político entre esses atores; a responsabilidade tem repercussões no cargo ou função do agente; a responsabilidade é uma forma de limite constitucional do exercício funcional do agente político; a responsabilidade tem processualística própria e normatizada; a responsabilidade ocorre no ambiente próprio do Estado de Direito. ${ }^{22}$

responsabilidade política. Revista Brasileira de Ciências Sociais, Vol. 12, 35, 1997, p.

42.

${ }^{21}$ Cf. BROSSARD, Paulo. O Impeachment: aspectos da responsabilidade política do

Presidente da República. São Paulo, SP: Saraiva, 1992.

${ }^{22}$ Cf. LOMBA, Pedro. Teoria da responsabilidade política. Coimbra: Coimbra, 2008. 


\section{A RESPONSABILIDADE POLÍTICA EM MODELOS CONCRETOS}

Entre os modelos de responsabilidade política analisados, escolhemos dois que surgem a partir das revoluções liberais e do advento do constitucionalismo. Primeiro, aquele do sistema inglês do governo misto e do governo parlamentar (ou do Executivo bipartido). ${ }^{23} \mathrm{O}$ segundo sendo o sistema de responsabilização, unipessoal presidencial, dos Estados Unidos da América. ${ }^{24}$

O sistema parlamentar britânico, como já dito, teve ao início fórmula de indistinção entre a responsabilidade criminal e a responsabilidade política. $\mathrm{O}$ agente público respondia criminalmente pelo exercício da função de governo. Com a afirmação do sistema parlamentar de governo,

${ }^{23}$ Cf. VILE, M.J.C. Constitutionalism and separation of powers. $2^{\text {nd }}$ ed. Indianapolis, IN: Liberty Fund, 1998; e McCLELLAN, James. Liberty, Order, and Justice: an introduction to the constitutional principles of American government. Indianapolis, IN: Liberty Fund, 2000. O modelo britânico serviu de molde aos sistemas parlamentares posteriores. Em suma, a forma de responsabilização encontra-se no binômio gabinete de governo x parlamento. Benjamin Constant descreve o modelo britânico de democracia parlamentar e indica como a fórmula adequada aos sistemas políticos ocidentais. Inclusive, a sugestão do poder moderador surge por inspiração do modelo britânico e como contraponto ao sistema de fiscalização constante dos representantes sugerido por Rousseau. Para Constant, o moderador seria capaz de estabilizar o sistema político evitando os abusos produzidos pela representação da soberania popular. Curiosamente, para Constant, os Ministros do governo responderiam politicamente mas não o chefe do Moderador. Cf. CONSTANT, Benjamim. Principes de politique, applicables a tous les gouvernemens représentatifset particulièrement a la constitution actuelle de la France. Paris: Chez Alexy Eymery, 1815, p. 33-58. O modelo foi adotado na Constituição brasileira de 1824 (BRASIL, 1824). A Constituição da Pennsylvania, 1776, formulou modelo de responsabilização direta, com fiscalização dos eleitores ao parlamento, e também ao judiciário, aproximando-se da ideia de Rousseau. Nesta Constituição, os membros do judiciário tinham mandato e podiam ser afastados; a existência de prazo de apreciação popular de toda a lei produzida pelo legislativo; previa ainda um conselho capaz de censurar os atos reputados contrários à Constituição. Cf. YALE LAW SCHOOL. Constitution of Pennsylvania - September 28, 1776. Filadelfia, PA: State of Pennsylvania., 1776.

${ }^{24}$ Cf. HAMILTON, Alexander; MADISON, James; JAY, John. American state papers, The Federalist. Chicago, IL: Encyclopaedia Britannica, 1952. 
o sistema foi abandonando a associação entre possíveis juízos criminais e políticos e, assim, direcionando a prática na responsabilidade pelo cargo - ou mandato. Já o sistema dos Estados Unidos da América incorporou uma forma híbrida, a associação entre o juízo criminal e o juízo político. ${ }^{25}$

Tomando-se uma visão abrangente, mas caracterizadora do que seja o sistema penal construído na modernidade, tem-se que o crime é figura típica descrita em norma legal. A tipicidade impõe a exigência de que a conduta abstrata que é o crime seja descrita em norma geral. As normas penais-criminais estampam condutas consideradas de alto valor social e, por isso, apresentam formas sancionatórias que privam a liberdade, ou mesmo com a condenação capital. Por isso, o direito penal apresenta natureza minimalista. Outros elementos caracterizadores do direito penal são, ao menos a partir da modernidade, a reserva do juízo criminal ao judiciário (vedando-se a concentração entre o agente que produz a norma e aquele que aplica a sanção no caso concreto), e a absoluta pessoalidade para a imputação e responsabilização (fugindo de sistemas de responsabilização grupal, familiar). A fórmula dos Estados Unidos da América conjugou a responsabilidade política com instituições típicas do direito penal: como a necessidade de tipificação em conduta típica de norma incriminadora; ao mesmo tempo, o juízo não é judicial, e sim pelo parlamento, algo típico da responsabilidade política.

O sistema dos Estados Unidos da América adotou a fórmula híbrida porque o sistema de governo presidencial apresenta característica que o diferencia do sistema parlamentar: o presidente não responde ao parlamento. Este diferencial dos sistemas parlamentar e presidencial estabelece as duas estruturas institucionais e processuais da responsabilização. No sistema parlamentar, a responsabilidade do chefe de governo faz-se ante a maioria parlamentar que o apoia; no sistema presidencial, a responsabilidade do chefe de governo (que é simultaneamente chefe de Estado) faz-se perante o povo eleitor. ${ }^{26}$

O sistema presidencial dos Estados Unidos da América adotou a estrutura híbrida ou dual de combinação de juízo político e de imputação penal, na qual se exige que o presidente possa ser responsabilizado desde

${ }^{25}$ Cf. BROSSARD, Paulo. O Impeachment: aspectos da responsabilidade política do Presidente da República. São Paulo, SP: Saraiva, 1992, p. 23-27.

${ }^{26}$ Cf. GOULART, Clóvis de Souto. Formas e sistemas de governo: uma alternativa para a democracia brasileira. Porto Alegre, RS: S.A. Fabris, 1995; e HAMILTON, Alexander; MADISON, James; JAY, John. American state papers, The Federalist. Chicago, IL: Encyclopaedia Britannica, 1952. 
que cometa ou incida nas condutas típicas definidas em normas legais ${ }^{27}$. No sistema parlamentar, de maneira diversa, a censura política, ou a desconfiança política, virão de conveniências políticas, ou de apoio político, ao sabor de maiorias ou bases de apoio parlamentares. Não há, no sistema parlamentar, a necessidade de imputação de conduta típica ao chefe de governo para a sua responsabilização (admite-se uma tipificação aberta, com grande margem discricionária). ${ }^{28}$

27 No caso brasileiro, as Leis n ${ }^{\circ} 27$ e 30/1892, e a Lei n ${ }^{\circ} 1.079 / 1950$, esta última ainda vigente, são as leis reguladoras do processo por crime de responsabilidade na história constitucional nacional. As Leis n 27 e 30/1892 obedeceram à lógica de partir o conteúdo em processual e material. A Lei $n^{\circ} 27 / 1892$ trazia a disciplina processual do crime de responsabilidade; a Lei $n^{\circ} 30 / 1892$, a disciplina material, descrevendo os tipos penais. A Lei n 1.079/1950 congregou os conteúdos num texto só. Cf. BRASIL. Decreto $n^{\circ}$ 27/1892. Disponível em:

$<$ http://www.planalto.gov.br/ccivil 03/decreto/Historicos/DPL/DPL0027.htm>. Acesso em: 31 de março de 2016; BRASIL. Decreto n 30/1892. Disponível em:

$<$ http://www.planalto.gov.br/ccivil 03/decreto/Historicos/DPL/DPL0030.htm>. Acesso em: 16 de março de 2016; e BRASIL. Lei $\mathbf{n}^{\circ}$ 1.079/1950. Disponível em:

$<$ http://www.planalto.gov.br/ccivil 03/LEIS/L1079.htm>. Acesso em: 13 de janeiro de 2016. Em 1967 foi editado o Decreto-Lei n 201/1967, que trouxe a responsabilização político-criminal dos Prefeitos Municipais, matéria ausente no texto da Lei ${ }^{\circ}$ $1.079 / 1950$. O texto padece de problema estrutural, pois agregou no mesmo texto matérias penais comuns com os crimes de responsabilidade propriamente ditos. Assim, o Decreto-Lei n 201/1967 traz crimes a serem julgados pelo Judiciário e crimes a serem julgados pelo órgão político, a Câmara Municipal. Cf. BRASIL. Decreto-Lei $\mathbf{n}^{\circ}$ 201/1967. Disponível em: $<$ http://www.planalto.gov.br/ccivil 03/decretolei/Del0201.htm>. Acesso em: 31 de março de 2016. Em 1983, foi editada a Lei ${ }^{\circ}$ 7.106/1983, que trouxe a disciplina dos crimes de responsabilidade do Governador do Distrito Federal. Cf. BRASIL. Lei $\mathbf{n}^{\circ}$ 7.106/1983. Disponível em:

<http://www.planalto.gov.br/ccivil 03/leis/L7106.htm>. Acesso em: 01 de abril de 2016. ${ }^{28}$ Cf. GOULART, Clóvis de Souto. Formas e sistemas de governo: uma alternativa para a democracia brasileira. Porto Alegre, RS: S.A. Fabris, 1995. Exemplo é o art. 49 da Constituição francesa: "Le Premier ministre, après délibération du Conseil des ministres, engage devant l'Assemblée nationale la responsabilité du Gouvernement sur son programme ou éventuellement sur une déclaration de politique générale". FRANÇA, ASSEMBLEIA NACIONAL. Constitution de la République française. Paris: Assemblée Nationale, 1958. Disponivel em: $<$ http://www.assembleenationale.fr/connaissance/constitution.asp\#titre 5>. Acesso em: 13 de janeiro de 2016. Por outro lado, no modelo parlamentar de governo, subsiste a possibilidade de responsabilização do presidente. Deve ser salientado que, neste sistema, o presidente é 
O sistema presidencial exige que alguém do povo eleitor faça a representação criminal contra o presidente. Na petição, esse eleitor deverá indicar quais as condutas previstas em lei, e tratadas como crime, podem ser imputadas ao presidente. $\mathrm{O}$ recebimento da denúncia, o processamento e o julgamento ocorrem nos órgãos políticos do Legislativo (e não no Judiciário). ${ }^{29}$ No sistema parlamentar, a censura, a desconfiança ou a rejeição da proposta de governo são patrocinadas no Legislativo. É aos partidos e às bancadas partidárias que o chefe de governo responde..$^{30}$

Tanto no sistema presidencial, como no sistema parlamentar, a sanção

somente chefe de Estado, e não chefe de governo. Por isso, está justificada a necessidade de responsabilização pelo sistema para-criminal já que as condutas praticadas pelo presidente são condutas que ofendem a existência do Estado, e não somente o jogo político do governo. Cf. o exemplo do art. 63, item 1, da Lei Fundamental da Alemanha: "The Bundestag or the Bundesrat may impeach the Federal President before the Federal Constitutional Court for wilful violation of this Basic Law or of any other federal law. The motion of impeachment must be supported by at least one quarter of the Members of the Bundestag or one quarter of the votes of the Bundesrat. The decision to impeach shall require a majority of two thirds of the Members of the Bundestag or of two thirds of the votes of the Bundesrat. The case for impeachment shall be presented before the Federal Constitutional Court by a person commissioned by the impeaching body". REPÚBLICA FEDERAL DA ALEMANHA, PARLAMENTO FEDERAL. Basic Law for the Federal Republic of Germany. Berlin: Deutscher Bundestag, 1949. Disponivel em: <https://www.bundestag.de/blob/284870/ce0d03414872b427e57fccb703634dcd/basic la w-data.pdf $>$. Acesso em: 13 de janeiro de 2016.

${ }_{29}$ Embora, como no sistema brasileiro, previsto na Lei $n^{\circ} 1.079 / 1950$, a presidência da sessão de julgamento fique ao cargo do presidente do STF, órgão judicial, e não ao presidente do Senado. Cf. BRASIL. Lei $\mathbf{n}^{\circ}$ 1.079/1950. Disponível em: $<$ http://www.planalto.gov.br/ccivil 03/LEIS/L1079.htm>. Acesso em: 13 de janeiro de 2016.

30 O projeto que antecedeu o texto constitucional de 1988 apresentava a seguinte redação no art. 105, tratando do Gabinete e da responsabilidade do $1^{\circ}$ Ministro: “Art. 105. Ocorre a demissão do Governo, em caso de: I - início de legislatura; II - rejeição do programa de governo; III - aprovação de moção de censura; IV - não aprovação do voto de confiança; V - morte ou renúncia do Primeiro-Ministro". BRASIL, ASSEMBLÉIA NACIONAL CONSTITUINTE. Assembléia Nacional Constituinte Projeto de Constituição. Brasília, DF: ANC, 1988. O projeto ficou pronto em fevereiro de 1988. Na sequência da tramitação o projeto foi alterado e abandonado o sistema parlamentar de governo. 
resulta na perda do cargo. ${ }^{31}$ No sistema presidencial, em função da forma híbrida, com a utilização dos elementos ainda presentes do sistema criminal, há sanções acessórias como a suspensão de direitos políticos ao presidente "condenado". Não há esta fórmula no sistema parlamentar, e o chefe de governo responde com o cargo - somente com a perda do cargo. O sistema parlamentar apresenta a forma de responsabilização com natureza impessoal e institucional (embora não deixe de ser responsabilidade subjetiva, já que é "um" chefe de governo que responde, com o seu governo). ${ }^{32} \mathrm{O}$ sistema presidencial tem nuanças acentuadamente pessoais já que deve ocorrer a imputação de uma conduta típica, abstratamente definida numa lei específica, ao presidente para que este responda.

Os dois casos ou modelos, do sistema presidencial e do sistema parlamentar, são disciplinados em normas jurídicas: no sistema presidencial de responsabilidade, com normas de legalidade estrita, com a figura dos "crimes de responsabilidade política" (que são crimes de julgamento político); no sistema parlamentar, com normas mais abertas e com maior margem discricionária, de aprovação de plano de governo, de votação de confiança e de desconfiança. Nos dois casos o juízo se faz nas casas legislativas ou parlamentares, por manifestação de maiorias parlamentares (de condenação, ou de aprovação, confiança e desconfiança).

A afirmativa de que são normatizados os processos de responsabilidade política, tanto no parlamentarismo como no presidencialismo, indica que são processos institucionalizados e com

${ }^{31}$ Nos sistemas semipresidencialistas conforme delimitado por Duverger em "Échec au Roi" como "président élu au suffrage universel disposant des prérogatives propres et coexistant avec un gouvernement responsable devant le Parlement" se busca uma responsabilidade dupla, tanto frente aos eleitores quanto ao parlamento e ao presidente, com mecanismos próprios. No entanto, conforme já adiantado por Duverger, essa dupla responsabilidade não expande de maneira inovadora os mecanismos já utilizados nas repúblicas parlamentares e presidencialistas. Há uma ampliação, mas não uma inovação no que tange a responsabilidade. DUVERGER, Maurice. Le système politique français: Droit constitutionnel et systèmes politiques. 18e éd. Paris: Presses Universitaires de France (PUF), 1985, p. 551.

${ }^{32}$ Cf. MILL, John Stuart. O governo representativo. Trad. Débora Ginza e Rita de Cássia Gondim. São Paulo, SP: Escala, 2006. 
previsões materiais e formais jurídicas. ${ }^{33} \mathrm{~A}$ responsabilização política deita-se no arrimo da rule of law, ou Estado de Direito, de juridicização da política. É uma das formalizações institucionais fortes das democracias pluralistas. É uma das formas clássicas do projeto da modernidade.

\section{A RESPONSABILIDADE POLÍTICA CONTEMPORÂNEA: UMA CRÍTICA A PARTIR DE PIERRE ANSART}

Em Mal-Estar ou fim dos amores políticos, Pierre Ansart analisa a forma como as democracias representativas distanciaram a política da afetividade e das emoções. ${ }^{34}$ Numa abordagem mais ampla, mostra os mal-estares e insatisfações da sociedade contemporânea que apresentam exteriorizações como: o abandono das esferas coletivas (o solipsismo); desinvestimento na vida política; o distanciamento do político; a privatização do afeto (o público distante do afeto).

Pierre Ansart descreve como a política assumiu formas abdicativas, negativas, e que tratam o político como algo inconspícuo. Segundo Ansart, as próprias formas de organização da política das democracias plurais conduzem ao localismo, às defesas comunitárias ou de pautas segmentadas que inibem os investimentos das massas ou da coletividade. Ansart menciona o fenômeno da pulverização dos investimentos políticos, ou seja, as ações políticas são direcionadas ao comunitário, ao local, às entidades e a formatos micro-orgânicos. Como consequência desse fenômeno, observa-se a dispersão e a forma coloidal da política,

${ }^{33}$ Cf. SINE, Alexandre. Responsabilité politique: de la fin du modèle weberien aux nouvelles figures de légitimation de l'action publique. Politique et Management Public, Vol. 19, 2, 2001.

${ }^{34}$ No que tange esse afastamento do "político" para com o "afeto" é perceptível que o modelo político atual, com uma racionalidade liberal assentada por John Rawls, propõe um modelo de organização sócio-política que não levam em consideração as emoções, por considerá-las prejudiciais à construção de uma racionalidade avalorativa pautada por indivíduos razoáveis, esses que não deixariam que suas perspectivas individuais perpassem para a realidade pública. Cf. RAWLS, John. A Theory of Justice. Cambridge, MA: Harvard University Press, 1971; e RAWLS, John. Political liberalism. New York, NY: Columbia University Press, 1993. Diante disso, configurase uma relação de não-existência das emoções. Além disso, as emoções, tais como medo e raiva, estão ligadas à gênese de movimentos sociais, significando um combustível fundamental para a ação política. Dessa forma, a legitimidade do regime democrático está intimamente relacionada com as emoções. 
com a presença de agentes sem coesão coletiva ou massiva. ${ }^{35}$ Outro aspecto dos sistemas competitivos das democracias representativas e partidárias é a condução do político ao risível e cômico. Há o mercado humorístico que transforma o político em objeto de insolência banal. Além da banalização da política no mundo do humor, a mídia realiza a abordagem dos fatos da política como se o participante fosse um espectador. O espectador é apenas um observador dos fatos da política e não um participante dos fatos da política. Assim, além da incredulidade, a "descrença" cria a disposição de espectador que observa com dúvida e ceticismo. ${ }^{36}$

Há, na crítica de Ansart, a análise de como as formas da política $d a$ modernidade foram pensadas e, a posterior, na modernidade (na hora em que se realizaram na modernidade) apresentaram os vincos do mal-estar. O que Ansart mostra é que o projeto institucional da modernidade tem o tagante de, ao invés de conduzir ao esclarecimento e às formas revolucionárias, direciona ao acomodamento, à distância displicente do mundo da política. $\mathrm{O}$ impacto da secularização e da institucionalização racional, o "desencantamento" do mundo, inclusive da política, não conduziu ao verismo, mas à contemporização e ao acomodatício. ${ }^{37}$ Tomando-se a ilustração simples e de contrastes para a descrição da teoria de Pierre Ansart, pode-se redigir um elenco dos cenários nos quais os investimentos políticos são realizados na atualidade. Nessa ilustração, há o confronto de dois cenários da política: o cenário da "descrença" da atualidade, que se realiza efetivamente e, de outro lado, o cenário da pretensão da política do projeto da modernidade, que não se realizou na forma original. ${ }^{38}$

Todo o cenário mostrado por Ansart é também atravessado por contradições. Os pulsos de emoção e de extroversão dos ânimos, a despeito das formas controladas e "desencantadas" 39 aparecem no jogo

35 ANSART, Pierre. Mal-estar ou fim dos amores políticos. Revista História \& Perspectivas, No. 25/26, 2002.

${ }^{36}$ ANSART, Pierre. Mal-estar ou fim dos amores políticos. Revista História \& Perspectivas, No. 25/26, 2002, p. 62-63.

${ }^{37}$ Cf. ANSART, Pierre. Mal-estar ou fim dos amores políticos. Revista História \& Perspectivas, No. 25/26, 2002.

${ }^{38}$ Cf. ANSART, Pierre. Mal-estar ou fim dos amores políticos. Revista História \& Perspectivas, No. 25/26, 2002.

39 Esse "desencantamento" é pluri-ideológico, abarcando, tanto setores da "esquerda", quanto da "direita". Aqueles apresentam como característica o protesto contra a democracia representativa e contra o modelo financeiro vigente. Os grandes 
político. O autor mostra como as instituições do jogo representativo se esforçam por canalizar investimentos coletivos e, com destaque, os momentos eleitorais - como se verá abaixo - são momentos de manifestação emocional, exteriorizando o que foi reprimido nas formas "desencantadas". ${ }^{40}$ A construção da ideia de responsabilidade política, nas democracias ocidentais, é uma das formas institucionais de "desencantamento" da política. Assim, as sociedades nas quais a organização da vida política seja "quente", repleta de ligações afetivas e intensidades emocionais, são distintas da racionalidade institucional, processualizada e juridicizada destas democracias. ${ }^{41}$ Embora haja a tendência ao encapsulamento emocional e afetivo da política, Ansart reconhece que, nas democracias representativas atuais, em momentos como os períodos eleitorais há o aflorar das paixões e das emoções. O jogo eleitoral é o momento propício às disputas apaixonadas, ao jogo do "perde e ganha", o momento do despertar emocional na política, nas sociedades "frias" da democracia pluralista. ${ }^{42}$

A responsabilidade política nas sociedades democráticas tem como

movimentos dessa categoria seriam o Indignados, na Espanha, e o Ocuppy que permeou vários países pelo globo, mas que teve seu centro em Nova York. Em âmbito partidário, talvez o exemplo mais pulsante dessa realidade seja o Podemos na Espanha. A percepção desses movimentos centraliza-se no fato de que a comunidade política "posta" já não responde aos anseios de seu sujeito político, o povo. Esses movimentos de contestação utilizam a bandeira da radicalização da democracia, contestando os pilares da democracia representativa em defesa de um modelo direto, uma "democracia real". Por outro lado, os movimentos (especialmente partidários) de extrema direita com viés populistas, apesar de apresentarem objetivos ideológicos diametralmente opostos às organizações/partidos de extrema esquerda, carregam em sua base de pensamento o povo como combustível para defender a refundação de uma identidade (nacional ou regional) em contrapartida a posições globais. No entanto, essa identidade é permeada pelo discurso xenofóbico, apresentando forte viés nacionalista, é utilizada uma visão do mundo "pré-globalização", o qual representaria um modelo de sociedade melhor. Esses movimentos de extrema "direita" apresentam (em regra) oposição ao atual modelo financeiro neoliberal, o qual relacionam como sendo uma consequência do fluxo migratório das últimas décadas.

${ }^{40}$ Cf. ANSART, Pierre. Mal-estar ou fim dos amores políticos. Revista História \& Perspectivas, No. 25/26, 2002.

${ }^{41}$ ANSART, Pierre. Mal-estar ou fim dos amores políticos. Revista História \& Perspectivas, No. 25/26, 2002, p. 55-56.

42 ANSART, Pierre. Mal-estar ou fim dos amores políticos. Revista História \& Perspectivas, No. 25/26, 2002, p. 73-77. 
pressuposto o vínculo entre governantes e governados, mas o vínculo está encapsulado na esfera do público, à margem de emoções e sentimentos (estes, na dicotomia público e privado das democracias ocidentais, encerrados na esfera do privado, as emoções pertenceriam no campo do privado). ${ }^{43} \mathrm{O}$ que ocorre nas democracias contemporâneas é a vulgarização da responsabilidade política e o distanciamento das formas normatizadas e de legalidade. As transformações da responsabilidade política podem ser a consequência dos próprios elementos caracterizadores da democracia representativa, e do distanciamento acomodatício em que as formas atuais se encontram, em contraste com o projeto da política da democracia liberal e representativa. Em suma, a responsabilização também sai da pretensão do verismo da forma institucional e normativa (do projeto da modernidade desencantada) para formas estranhas da incredulidade e do distanciamento da política. As formas estranhas de incredulidade e distanciamento da política significam também que a responsabilidade política tende a suprimir as formas emocionais e "quentes" da política. ${ }^{44}$

${ }^{43}$ Carl Schmitt critica como as formas sacralizadas do político foram racionalizadas pelo pensamento racionalista a partir do século XVIII. Sustenta Schmitt que a soberania é decorrência da sacralidade do poder e do ato majestático de ascensão do soberano. Assim, as sociedades plurais são sociedades que dessacralizam o poder. Por consequência, a sacralidade do poder está associada ao regime unitário, à verticalização e à capacidade do soberano para tomar a decisão política: “The ideia of the modern constitucional state triumphed together with deism, a theology and metaphysics that banished the miracle from the world. This theology and metaphysics rejected not only the transgression of the laws of nature through an exception brought about by direct intervention in a valid legal order. The rationalism of the Enlightenment rejected the exception in every form". SCHMITT, Carl. Political theology. Four chapters of the concept of sovereignty. Cambridge, MA: The MIT Press, 1985, p. 36-37. Ansart mostra como há dois estereótipos entre as sociedades ditas "plurais" e as sociedades "unitárias". O unitário vê as pessoas das sociedades plurais como superficiais e irresponsáveis, por adesão e legitimação perfunctória do poder e do soberano. O plural vê as pessoas das sociedades unitárias como dóceis e ingênuas, crédulas de algo sagrado e imanente do poder e do soberano. ANSART, Pierre. Malestar ou fim dos amores políticos. Revista História \& Perspectivas, No. 25/26, 2002, p. 63. A descrição sobre a decisão do soberano, a possibilidade de invocar a sacralidade para a decisão soberana, encontra-se em AGAMBEN, Giorgio. Estado de Exceção. São Paulo, SP: Boitempo, 2004.

${ }^{44}$ Daí a necessidade de construção de uma racionalidade "quente", que não só desvele o véu do racionalismo liberal (frio) mas também surja com viés propositivo. A esse 
Como Pierre Ansart menciona, os sistemas eleitorais e representativos plurais são sistemas de concorrência e de competição. Os sistemas partidários de democracia competitiva oferecem o ambiente de decomposição recíproca dos concorrentes no processo eleitoral. ${ }^{45} \mathrm{~A}$

propósito, Boaventura de Sousa Santos aponta um caminho para uma nova perspectiva de razão, indicando uma estrutura social que deve, como transição e continuamente, passar por um processo de emancipação social. Para o autor, as emoções devem assumir seu lugar, passando não pela negação da razão estruturante (razão fria), mas a complementando: "Hay una dimensión emocional en el conocimiento que nosotros manejamos muy mal, y entonces debemos ver lo que distingue las dos corrientes de nuestra vida, tanto en las sociedades como en los individuos: la corriente fría y la corriente caliente. Todos tenemos las dos: la corriente fría es la conciencia de los obstáculos, la corriente caliente es la voluntad de sobrepasarlos. Las culturas se distinguen por la primacía que dan a la corriente fría o a la corriente caliente. Pienso que la corriente fría es absolutamente necesaria para que uno no se engañe, y también la corriente caliente es muy importante para no desistir facilmente". SANTOS, Boaventura de Souza. Una nueva cultura política emancipatoria. In: Boaventura de Souza Santos. Renovar la teoría crítica y reinventar la emancipación social: encuentros en Buenos Aires. Buenos Aires: Universidade de Buenos Aires, 2006, p. 12.

45 Há a tentativa de Paulo Sergio Peres de mensuração do que é um sistema de um sistema de volatilidade eleitoral: “Consideremos, por exemplo, as várias medidas de proporcionalidade da representação. Todas elas têm como motivação teórica o problema da representação política e a preocupação normativa com alguma forma de justiça distributiva. A cosmologia que lhe dá suporte assenta-se na perspectiva liberal acerca do mundo político, articulando a soberania popular com o princípio da representação e o constitucionalismo. [...] Mas, será mesmo que a estabilidade eleitoral é sempre boa e, contrariamente, a instabilidade eleitoral é sempre ruim? Em decorrência de sua orientação teórica e valorativa, os estudos realizados sobre o tema julgavam que sim, afinal, já estavam "pré-programados" para interpretar a volatilidade eleitoral como um sinal do aterrorizador 'espectro da instabilidade' política, conforme já observado por Bartolini e Mair (1990)." PERES, Paulo Sergio. Institucionalização do sistema partidário ou evolução da competição? Uma proposta de interpretação econômica da volatilidade eleitoral. Opinião pública, Vol. 19, 1, 2013, p. 23/27. Assim, o pluralismo eleitoral e partidário apresenta a pretensão de que, embora admita vários atores, não admite propriamente a dispersão e a não repetição de atores/resultados. $\mathrm{O}$ sistema quer apresentar a natureza de ampliador de fluxos, emoções e demandas afetivas mas, ao mesmo tempo, produz decepções desses fluxos e demandas. ANSART, Pierre. Mal-estar ou fim dos amores políticos. Revista História \& Perspectivas, No. 25/26, 2002, p. 57. 
decomposição ocorre e atinge líderes e partidos. A decomposição neste cenário competitivo é marcada pela perda do respeito entre os contendores. ${ }^{46} \mathrm{Na}$ atualidade, a política é a técnica da procura do distanciamento e do estranhamento das pessoas às teses rivais; $e$ a criação de desconfianças e suspeitas sobre as teses rivais; é a técnica dos escândalos, dos estereótipos, das conotações desvalorizantes. A política não é mais a técnica de construção de argumentos para demonstrar fraquezas do adversário, ou mesmo deixa de ser a apresentação de propostas, ou deixa de ser a pretensão de apresentação de propostas razoáveis. ${ }^{47}$ A política perde a natureza de convencimento e persuasão para se tornar o jogo de produção de desvios e descrenças, atacando as adesões afetivas existentes. A proeminência da mídia substitui os debates parlamentares (ou os debates tornam-se caudatários de exposições midiáticas). Pierre Ansart utiliza a expressão "máquinas de fazer descrer" para a compreensão deste fenômeno de decomposição, perda de respeito

${ }^{46}$ Para Ansart, o sistema plural não encoraja os movimentos massivos. A dispersão do sistema gera a fragmentação que é o obstáculo às causas que envolvem as massas. Há um paralelo com as preocupações de Jean-Jacques Rousseau, que entendia que toda a associação, ou facção, era risco à vontade geral. Embora a tese de Rousseau possa ser considerada a negação dos sistemas de representação partidária, ou de democracia partidária, a competição representativa que acabou por vingar no século XIX imaginava o parlamento representativo como a arena dos debates propositivos da política. Assim, a preocupação de Rousseau com o facciosismo não foi considerada relevante nos sistemas partidários e representativos do século XIX, ou mesmo do início do século XX. É, na atualidade, que o sistema partidário se apresenta como o sistema do facciosismo com a fórmula da descrença e do desinvestimento no fluxo político: "Mas quando se estabelecem facções, associações parciais às expensas da grande, a vontade de cada umas dessas associações torna-se geral relativamente as seus membros e particular ao Estado; poder-se-ia dizer então que não há mais tantos votantes quanto homens, mas apenas enquanto associações. As diferenças tornam-se menos numerosas e dão um resultado menos geral. Enfim, quando umas dessas associações for tão grande que venha a se impor sobre todas as outras, não mais se terá uma soma de pequenas diferenças, mas uma diferença única; então não existe mais vontade geral, e a opinião que a manifesta é apenas uma opinião particular". ROUSSEAU, Jean-Jacques. Do contrato social e discurso sobre a economia política. São Paulo, SP: Hemus, 1981, p. 40-41.

${ }^{47}$ ANSART, Pierre. Mal-estar ou fim dos amores políticos. Revista História \& Perspectivas, No. 25/26, 2002, p. 60. 
e de descrença. ${ }^{48}$

As formas contemporâneas de realização da responsabilidade política são então instrumentos - dispositivos - das formas de "descrença" da política ${ }^{49}$ Há o paradoxal retorno às formas primitivas de criminalização da responsabilidade política. A responsabilidade política torna-se, na forma descaracterizada, inclusive um substituto à regularidade do processo eleitoral. Justamente, a responsabilidade política torna-se a "ferramenta" para superar o inconveniente do "investimento" políticoemocional das eleições..$^{50}$

Uma situação peculiar dos desvios da responsabilização política é a tentativa de afastar o político do momento emocional da eleição para o momento sóbrio e técnico do ajuste de contas na esfera criminal. Assim,

${ }^{48}$ Cf. ANSART, Pierre. Mal-estar ou fim dos amores políticos. Revista História \& Perspectivas, No. 25/26, 2002.

${ }^{49}$ Cf. AGAMBEN, Giorgio. O que é o contemporâneo? E outros ensaios. Chapecó, SC: Argos, 2009, p. 25-51.

${ }^{50}$ As demonstrações de como as formas de responsabilização recrudesceram nas democracias contemporâneas é quantitativo. No século passado, houve o caudaloso processo de impeachment do presidente Andrew Johnson, no posterior à guerra civil americana e ao assassinato de Abraham Lincoln. Houve o recebimento da denúncia pela Casa dos Representantes. A absolvição ocorreu no Senado, por estreita margem de votos. Cf. ROSS, Edmund G. History of the Impeachment of Andrew Johnson, President of the United States: by the House of Representatives and his trial by the Senate for high crimes and misdemeanors in Office. New York, NY: Burt Franklin, 1868. Na década de 70, houve o caso de Richard Nixon com a renúncia antes do início do julgamento de crime de responsabilidade. Depois, o instituto ficou sem utilização significativa por décadas (salvo hipóteses remotas de agentes públicos ocupantes de cargo que não o presidencial). No Brasil, em 1954, a denúncia contra o presidente Getúlio Vargas não foi aceita pela Câmara dos Deputados. Cf. D’ ARAÚJO, Maria Celina. A herança de Vargas: a crise de 1954 e a carta testamento. Disponível em: $<$ https://cpdoc.fgv.br/producao/dossies/Jango/artigos/NoGovernoGV/A heranca de V argas $>$. Acesso em: 02 de abril de 2016. O julgamento relâmpago de João Goulart não se fez em parâmetros de legalidade já que a imputação de que o presidente não se encontrava em território nacional sequer era verdadeira. A vacância foi decretada no clima do golpe em andamento e, por isso, não pode ser considerada a forma típica de crime de responsabilidade. É a partir dos anos 90 que há a sucessão de casos em quantidade sem parâmetros anteriores, prodigalizando-se o crime de responsabilidade: Brasil, com F. Collor; Venezuela, com C. A Perez; Filipinas, com Estrada e, depois, com Arroyo; Equador, com Bucaram; Paraguai, com Lugo; Ucrânia com Yanukovych. 
os resultados da "festa eleitoral" podem ser descontextualizados e "afastados da emoção política" pelas atuações do juízo criminal, ou mesmo da jurisdição eleitoral. O juízo criminal pode, inclusive, servir de embuço à emissão de juízos morais sobre as condutas do governante ${ }^{51}$, ou juízos técnicos neutros. ${ }^{52}$

O recurso ao juízo criminal, ou a associação indevida entre responsabilidade criminal e responsabilidade política, encontra-se naquilo que Ansart chama de redução progressiva das posições positivas do adversário..$^{53} \mathrm{Ou}$ também, a redução da estima, admiração e do respeito ao adversário. O flerte com o juízo criminal auxilia na criação de, muito mais que um estereótipo da incompetência e fracasso do adversário, o verdadeiro estigma da corrupção e da prática criminosa.$^{54}$

Os elementos materiais que alimentam a responsabilização política são ditados por pautas de mídia e pela execração e ridicularização do

${ }^{51} \mathrm{O}$ caso ilustrativo é a frustrada abertura de processo por crime de responsabilidade contra o presidente Bill Clinton. Supostamente, o presidente havia cometido perjúrio ao influenciar o testemunho de pessoa com quem tivera relação sexual (a estagiária Monica Levinski). O juízo original do crime de responsabilidade foi turvado por série de juízos escandalizadores da vida sexual do presidente. EAGLETON, INSTITUTE OF POLITICS. The Impeachment of President Clinton. Disponível em:

$<$ http://www.eagleton.rutgers.edu/research/americanhistory/ap clintonimpeach.php $>$. Acesso em: 11 de janeiro de 2016.

52 “Uma representação comum faz os aparelhos de o Estado aparecerem como lugares neutros, pouco investidos afetivamente regidos apenas pela monotonia do funcionamento burocrático. As paixões políticas incidiriam intensamente sobre os partidos, sobre os heróis da cena política e se esgotariam nessas contendas." ANSART, Pierre. Mal-estar ou fim dos amores políticos. Revista História \& Perspectivas, No. 25/26, 2002, p. 78. Nos acontecimentos recentes da política brasileira, a neutralização da responsabilidade política como se o suposto delito da presidente fosse motivado por ilícitos financeiros, avaliados por um "juízo técnico de contas" - do Tribunal de Contas.

${ }^{53}$ A figura do "adversário" é muito cara para a teoria política, apresenta o caráter geralmente binário das disputas e o encapsulamento destas em discursos superficiais e pouco propositivos.

${ }^{54}$ ANSART, Pierre. Mal-estar ou fim dos amores políticos. Revista História \& Perspectivas, No. 25/26, 2002, p. 60-61. No caso brasileiro, de 1992, o fato paradoxal do crime de responsabilidade de Fernando Collor ter sido acompanhado da absolvição no juízo criminal. As supostas práticas de delitos alimentaram o juízo de responsabilidade política, mas, no caso do juízo criminal, houve a absoluta ausência de provas dos ilícitos penais imputados. 
agente político. Confiança ou desconfiança constroem-se pela exposição midiática. A prática de possível crime de responsabilidade faz-se mais por impulso midiático do que por capitulação à legalidade estrita. ${ }^{55}$ Nos sistemas parlamentares, a responsabilização deixou de atender aos quesitos de confiança/desconfiança para se pautar em cataduras ou análises perfunctórias da sustentação do gabinete..$^{56}$

$\mathrm{O}$ abandono da legalidade estrita anda na mesma velocidade com aquilo que Ansart mostra como o estranhamento e o distanciamento das pessoas da política. ${ }^{57} \mathrm{~A}$ vulgarização e a banalização da política fazem com que a responsabilidade política passe a ser tratada com frivolidade, ou de maneira superficial. ${ }^{58}$

${ }^{55}$ Como no caso do afastamento por crime de responsabilidade do presidente do Paraguai, Fernando Lugo, no qual a materialidade das condutas típicas foi abandonada por pretensão de adversários, à margem do processo eleitoral ordinário. Cf. SIRIO, Artur de Oliveira. O Impeachment de Lugo: Uma mistura de interesses, oportunismo e valores discutíveis. Conjuntura internacional, 2012. Disponível em: $<$ https://pucminasconjuntura.wordpress.com/2012/09/28/o-impeachment-de-lugo-umamistura-de-interesses-oportunismo-e-valores-discutiveis/>. Acesso em: $29 \mathrm{de}$ dezembro de 2015. Outro caso curioso foi o afastamento do presidente do Equador, em 1997, Abdala Bucaram por "incapacidade mental", fundamentação assaz à margem da materialidade da responsabilidade política. Cf. CONGRESO NACIONAL DE ECUADOR. Libro autentico de legislacion ecuatoriana, 1997. Disponível em: $<\underline{\text { http://apps.asambleanacional.gob.ec/proleg/publico/navegar/navegar documento.asp }}$ ?codigo=I-97-065-R\&path=/autenticos/19961997\&numero=1\&hojas=3\&tipo=AUT\&defWidth=992\&serial=2396 $>$. Acesso em: 08 de janeiro de 2016.

${ }^{56} \mathrm{O}$ caso japonês mostra a alta rotatividade dos gabinetes: de 2006 ao presente, o Japão teve 7 gabinetes diferentes. O Partido Democrático do Japão obteve 308 cadeiras, das 480 em disputa, em 2009. Na eleição de 2012, caiu para 57 cadeiras (perdendo 267 cadeiras), mostrando a fragilidade e fragmentação das forças políticas parlamentares. A Bélgica permaneceu 541 dias sem governo, sem a capacidade de aprovação política de um gabinete (2010-2011). No caso belga, a atomização de interesses regionais, comunitarismos e localismos levaram à fragmentação.

${ }^{57}$ ANSART, Pierre. Mal-estar ou fim dos amores políticos. Revista História \& Perspectivas, No. 25/26, 2002, p. 63.

${ }^{58}$ Em pesquisa realizada em 2015, 63\% dos entrevistados se posicionaram de maneira favorável à abertura de processo por crime de responsabilidade contra a presidenta. Na mesma pesquisa, 37\% disseram não ter ideia das consequências do processo.

Curioso é que $75 \%$ do universo dos favoráveis disse que tal opção se deu por causa do envolvimento na operação lava jato, já que a presidenta não tinha, à época, qualquer 


\section{CONSIDERAÇÕES FINAIS}

A forma como a responsabilidade política tem sido encaminhada indica que este processo/juízo caminha para a caracterização crítica que Ansart faz da democracia representativa contemporânea. Os juízos de responsabilidade política são formas nas quais os eleitores são mantidos à distância. A caracterização de possíveis elementos materiais de responsabilização é diluída por fundamentações negativas e de incredulidade. As formas da responsabilização política privilegiam os agentes julgadores distantes do jogo eleitoral e que acentuam a ideia estereotipada de que há a clivagem entre o jogo emocional do político, e a apreciação neutral de julgadores da responsabilidade política.

De forma paradoxal, a responsabilização política afasta-se da forma tradicional noética do projeto da modernidade e, simultaneamente, das possibilidades de emoções na política. A forma da responsabilização política acaba por minorar as possibilidades ativas e emocionais do jogo político e o desloca às decisões marcadas pela nugacidade, e para além das estruturas partidárias e institucionalizadas.

Dessa forma, compreende-se que a crítica de Ansart é extremamente relevante para o contexto dos desenhos institucionais que, em um Estado Democrático de Direito, buscam legitimidade no povo. A "descrença" deste, ou melhor, o "fim dos amores políticos" é sinal importante para se repensar os modelos representativos e o próprio sistema de responsabilidade política dos Estados e Sociedades atuais.

\section{REFERÊNCIAS}

AGAMBEN, Giorgio. Estado de Exceção. São Paulo, SP: Boitempo, 2004.

AGAMBEN, Giorgio. O que é o contemporâneo? E outros ensaios. Chapecó, SC: Argos, 2009.

imputação concreta dela decorrente. Cf. MENDONÇA, Ricardo. Maioria apoia abertura de processo de impeachment, mostra Datafolha. Folha de São Paulo, 2015. Disponível em: <http://www1.folha.uol.com.br/poder/2015/04/1615424-maioria-querimpeachment-de-dilma-e-nao-conhece-vice.shtml>. Acesso em: 30 de dezembro de 2015. 
ANSART, Pierre. Mal-estar ou fim dos amores políticos. Revista História \& Perspectivas, No. 25/26, 2002.

BRASIL, ASSEMBLÉIA NACIONAL CONSTITUINTE. Assembléia Nacional Constituinte - Projeto de Constituição. Brasília, DF: ANC, 1988.

BRASIL. Constituição do Império do Brazil. Rio de Janeiro, RJ:

Presidência da República, 1824.

. Decreto $n^{\circ}$ 27/1892. Disponível em:

$<$ http://www.planalto.gov.br/ccivil 03/decreto/Historicos/DPL/DPL0027 .htm>. Acesso em: 31 de março de 2016.

. Decreto $n^{\circ}$ 30/1892. Disponível em:

$<$ http://www.planalto.gov.br/ccivil 03/decreto/Historicos/DPL/DPL0030 .htm>. Acesso em: 16 de março de 2016.

. Decreto-Lei ${ }^{\circ}$ 201/1967. Disponível em:

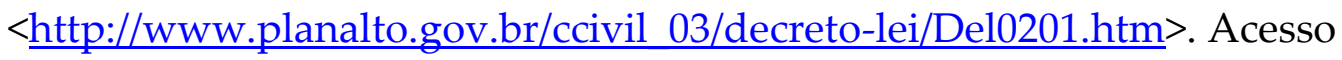
em: 31 de março de 2016.

. Emenda Constitucional n ${ }^{\circ}$ /1961. Disponível em:

$<\underline{\text { http://www.planalto.gov.br/ccivil 03/Constituicao/Emendas/Emc ante }}$ rior1988/emc04-61impressao.htm>. Acesso em: 15 de janeiro de 2016.

. Lei $\mathbf{n}^{\circ}$ 7.106/1983. Disponível em:

$<$ http://www.planalto.gov.br/ccivil 03/leis/L7106.htm>. Acesso em: 01 de abril de 2016.

. Lei $\mathbf{n}^{\circ}$ 1.079/1950. Disponível em:

$<$ http://www.planalto.gov.br/ccivil 03/LEIS/L1079.htm>. Acesso em: 13 de janeiro de 2016. 
BROSSARD, Paulo. O Impeachment: aspectos da responsabilidade política do Presidente da República. São Paulo, SP: Saraiva, 1992.

CAMÕES, Luís Vaz de. Os Lusíadas, 2008. Disponível em:

$<$ http://oslusiadas.org/x/146.html $>$. Acesso em: 20 de dezembro de 2015.

CHEIBUBI, José Antônio; PRZEWORSKI, Adam. Democracia, eleições e responsabilidade política. Revista Brasileira de Ciências Sociais, Vol. 12, 35, 1997.

CONGRESO NACIONAL DE ECUADOR. Libro autentico de legislacion ecuatoriana, 1997. Disponível em: $<\underline{\text { http://apps.asambleanacional.gob.ec/proleg/publico/navegar/navegar }}$ documento.asp?codigo=I-97-065-R\&path=/autenticos/1996$1997 \&$ numero $=1 \&$ hojas $=3 \&$ tipo $=$ AUT\&defWidth $=992 \&$ serial $=2396>$. Acesso em: 08 de janeiro de 2016.

CONSTANT, Benjamim. Principes de politique, applicables a tous les gouvernemens représentatifset particulièrement a la constitution actuelle de la France. Paris: Chez Alexy Eymery, 1815.

D'ARAÚJO, Maria Celina. A herança de Vargas: a crise de 1954 e a carta testamento. Disponível em: $<$ https://cpdoc.fgv.br/producao/dossies/Jango/artigos/NoGovernoGV/A heranca de Vargas>. Acesso em: 02 de abril de 2016.

DRAGO, Roland. La notion dóbligation: droit publique et droit privé. Archives de philosophie du droit, Vol. 44, 2000.

DUVERGER, Maurice. Le système politique français: Droit constitutionnel et systèmes politiques. $18^{\mathrm{e}}$ éd. Paris: Presses Universitaires de France (PUF), 1985. 
EAGLETON, INSTITUTE OF POLITICS. The Impeachment of President Clinton. Disponível em:

$<$ http://www.eagleton.rutgers.edu/research/americanhistory/ap clintoni mpeach.php>. Acesso em: 11 de janeiro de 2016.

FILMER, Sir Robert. Patriarcha of the Natural Power of Kings. London: Richard Chiswell, 1680.

FRANÇA, ASSEMBLEIA NACIONAL. Constitution de la République française. Paris: Assemblée Nationale, 1958. Disponivel em:

$<$ http://www.assembleenationale.fr/connaissance/constitution.asp\#titre 5>. Acesso em: 13 de janeiro de 2016.

GORGONI, Guido. La responsabilité comme projet. Réflexions sur une responsabilité juridique " prospective ». In: EBERHARD, C. Traduire nos responsabilités planétaires.Recomposer nos paysags juridiques. Bruxelas: Bruylant, 2008.

GOULART, Clóvis de Souto. Formas e sistemas de governo: uma alternativa para a democracia brasileira. Porto Alegre, RS: S.A. Fabris, 1995.

HAMILTON, Alexander; MADISON, James; JAY, John. American state papers, The Federalist. Chicago, IL: Encyclopaedia Britannica, 1952.

HOBBES, Thomas. Hobbes's Leviathan reprinted from the edition of 1651. Oxford/Indianapolis, IN: Clarendon Press/Liberty fund, 1909.

LAURIS, Élida. Entre a neutralidade política e a responsabilidade social: os dilemas de afirmação da independência judicial no Estado Moderno. Meritum, Vol. 6, 2, 2011. 
LOCKE, John. Dois tratados sobre o governo. São Paulo, SP: Martins Fontes, 1998.

LOMBA, Pedro. Teoria da responsabilidade política. Coimbra: Coimbra, 2008.

MAQUIAVEL, Nicolau. O Príncipe. São Paulo, SP: Martin Claret, 1999.

MCCLELLAN, James. Liberty, Order, and Justice: an introduction to the constitutional principles of American government. Indianapolis, IN: Liberty Fund, 2000.

MENDONÇA, Ricardo. Maioria apoia abertura de processo de impeachment, mostra Datafolha. Folha de São Paulo, 2015. Disponível em: <http://www1.folha.uol.com.br/poder/2015/04/1615424-maioriaquer-impeachment-de-dilma-e-nao-conhece-vice.shtml>. Acesso em: 30 de dezembro de 2015.

MILL, John Stuart. O governo representativo. Trad. Débora Ginza e Rita de Cássia Gondim. São Paulo, SP: Escala, 2006.

PERES, Paulo Sergio. Institucionalização do sistema partidário ou evolução da competição? Uma proposta de interpretação econômica da volatilidade eleitoral. Opinião pública, Vol. 19, 1, 2013.

RAWLS, John. A Theory of Justice. Cambridge, MA: Harvard University Press, 1971.

. Political liberalism. New York, NY: Columbia University Press, 1993.

REPÚBLICA DEMOCRÁTICA ALEMÃ. Democracia Socialista:

Participação nas decisões, Responsabilidade, Direitos, Liberdades. 
Dresden: PANORAMA RDA - Agência de Imprensa para o estrangeiro, 1981.

REPÚBLICA FEDERAL DA ALEMANHA, PARLAMENTO FEDERAL. Basic Law for the Federal Republic of Germany. Berlin: Deutscher Bundestag, 1949. Disponivel em:

$<$ https://www.bundestag.de/blob/284870/ce0d03414872b427e57fccb7036 34dcd/basic law-data.pdf $>$. Acesso em: 13 de janeiro de 2016.

ROSS, Edmund G. History of the Impeachment of Andrew Johnson, President of the United States: by the House of Representatives and his trial by the Senate for high crimes and misdemeanors in Office. New York, NY: Burt Franklin, 1868.

ROUSSEAU, Jean-Jacques. Do contrato social e discurso sobre a economia política. São Paulo, SP: Hemus, 1981.

SANTOS, Boaventura de Souza. Una nueva cultura política emancipatoria. In: Boaventura de Souza Santos. Renovar la teoría crítica y reinventar la emancipación social: encuentros en Buenos Aires. Buenos Aires: Universidade de Buenos Aires, 2006.

SCHMITT, Carl. Political theology. Four chapters of the concept of sovereignty. Cambridge, MA: The MIT Press, 1985.

. Teoría de la constitución. Madri: Alianza Editorial, 1996.

SINE, Alexandre. Responsabilité politique: de la fin du modèle weberien aux nouvelles figures de légitimation de l'action publique. Politique et Management Public, Vol. 19, 2, 2001.

SÍRIO, Artur de Oliveira. O Impeachment de Lugo: Uma mistura de interesses, oportunismo e valores discutíveis. Conjuntura internacional, 2012. Disponível em: 
$<$ https://pucminasconjuntura.wordpress.com/2012/09/28/oimpeachment-de-lugo-uma-mistura-de-interesses-oportunismo-evalores-discutiveis/>. Acesso em: 29 de dezembro de 2015.

TABORDA, Marem Guimarães. Estudo sobre o procedimento civil e as obrigações no direito romano clássico. Disponível em: $<$ http://www.ufrgs.br/ppgd/doutrina/taborda2.htm $>$. Acesso em: $17 \mathrm{de}$ julho de 2016.

VIEIRA, Mónica Brito. The Elements of Representation in Hobbes: Aesthetics, Theatre, Law, and Theology in the Construction of Hobbes's Theory of State. Boston, MA: Brill, 2009.

VILE, M.J.C. Constitutionalism and separation of powers. $2^{\text {nd }} \mathrm{ed}$. Indianapolis, IN: Liberty Fund, 1998.

YALE LAW SCHOOL. Constitution of Pennsylvania - September 28, 1776. Filadelfia, PA: State of Pennsylvania., 1776.

Reponsabilidade Política: uma contextualização crítica a partir de Pierre Ansart Political Accountability: a critical contextualization from Pierre Ansart

Submetido em: 2016-04-06 Aceito em: 2016-07-10 